\title{
The Socialist Core Values Leading the Campus Culture Construction in University
}

\author{
Junwei Shi ${ }^{1}$ \\ ${ }^{1}$ Hebei Agricultural University, \\ Baoding, Hebei, China
}

\begin{abstract}
The socialist core values leading the Campus Culture is an inevitable requirement of social and cultural construction, the practical needs of the construction of campus culture, socialist core values leading the construction of campus culture and talents inherent consistency of training objectives. Currently, the complex environment facing the construction of university campus culture and highlighting the issue itself, we urgently requires construction of campus culture to highlight the leading socialist core values of education, at the same time, the socialist core value education should be effective in the practice using the campus culture carrier and ultimately socialist core values education and culture complement of Campus.
\end{abstract}

Keywords:Socialist core values; Campus culture; Colleges and Universities

\section{Introduction}

Socialist core values are embodied an advanced socialist culture with Chinese characteristics, is the essence of socialist advanced culture with Chinese characteristics. As the development of university campus culture in cultural heritage, not only embodies the core spirit of the University, but also reflects the university's comprehensive strength. In Campus Culture must lead the socialist core values of Campus Culture, and comprehensively improve the quality of students, especially their ideological and political quality.

\section{The importance of leading the socialist core values of Campus Culture}

The socialist core values in the current value of a pluralistic society, based on the background of the initiative. Actively cultivate and practice the socialist core values is a major strategic task of the Party's 18 report. CPC Central Committee "on the cultivation and practice the socialist core values of opinions" put forward "to cultivate and practice the socialist core values into the whole process of national education." Colleges and universities train high-quality personnel at home are, how best to widen the main channel, build a strong main front, truly cultivate and practice the socialist core values important platform, is an important task facing universities. Among them, the socialist core values to lead the construction of campus culture, making its program and the heart and soul, in the building of high quality university on the basis of material culture, efforts to create a spirit of reform and innovation campus culture, campus system culture of democracy and equality, professional integrity campus behavior culture, is an important way to cultivate and practice the socialist core values of Colleges and Universities.

Xi Jinping, general secretary of the study at the Peking University stressed: core values carrying a nation, a nation of spiritual pursuit, is the most durable and most profound strength. Values determine the future of the youth value orientation of the whole society, and youth and in a period of the formation and establishment of values, the values of the period to develop a good job is very important. The majority of young people from now, start from ourselves, studious, virtue, discernment, probity, socialist core values become their basic follow, and personally strongly be extended to the whole of society to strive towards China Dream the great practice of creating their own wonderful life.

Campus culture is to teachers and students for participation, thought concept, the pursuit of success, moral standard and value orientation of the campus environment for geographical space, in the spirit of the university is a core feature of the group culture, is an important way to cultivate talents in Colleges and universities, Health Sciences, keeping pace with the times and excellent campus culture can exert a subtle influence on students. University campus culture is one of the important parts of the university campus value system, and what kind of campus culture, will foster what kind of students." Opinions of the Central Communist Youth League of the Ministry of education on strengthening and improving the cultural construction of the school campus "( Education and Politics[2004]16 Number): "The campus culture is an important part of the advanced socialist culture. It is of great significance to strengthen the construction of campus culture for promoting the reform and development of higher education, strengthening and improving the ideological and political education for college students and improving the comprehensive quality of college students.." Values are the core of culture, what kind of culture direction, what culture 
is to build, what kind of values are adhered to and advocated. The socialist core value system is the socialist system of inner spirit and life of the soul, only a profound understanding and correctly grasp the socialist core value system, guarantee the socialist in the right direction, to the cultural construction in focus, seize the fundamental.To always maintain the advanced nature of the campus culture, we must adhere to the socialist core value system to guide the construction of campus culture. Only in this way can we persevere in the prosperity and development of campus culture in the right direction, in order to give full play the function of advanced campus culture, promote students' all-round development;Give full play to the educational function of advanced campus culture, guide the staff and students to establish a correct world outlook, outlook on life and values, for the teacher career development and cultivation of teachers' ethics and student's growth and success to provide intellectual support and spiritual support, the training goal of high-quality personnel provide a solid cultural foundation and the thought foundation.This is a great and far-reaching significance for building a socialist harmonious society and accelerating the great goal of socialist modernization.

\section{At present, the socialist core value system leads the outstanding problems of university campus culture construction}

To strengthen the unified guidance of Marx doctrine on the construction of university campus culture

Marx is the fundamental guiding ideology of the party and state, and it is the powerful weapon of thought that we recognize and reform the world, and the soul of the socialist core value system.. The theoretical foundation of wavering in the guiding position of Marxism, it will shake up Chinese characteristic socialism and shake the whole Party and the people's solidarity consistent walk the road of socialism with Chinese characteristics, determination and confidence. Therefore, in the construction of campus culture in Colleges and universities must always adhere to the unified Marxism's guiding position + however since a period of time, the Marxism in the construction of campus culture in Colleges and universities centralized guiding position is weakening, such as individual teachers do not have a strong sense of politics, political position is not firm, the lack of sense of political responsibility and, not a correct understanding of the purpose of socialist universities, can not fully understand the as university teachers shoulder the important responsibility, the knowledge teaching and personnel training goal apart. Speaking only in the teaching of academic, regardless of political, only talk about knowledge, regardless of ideology, just to teach, education, ideological recognition deviation in their teaching deviate from the correct political direction; some teachers and students of Marxist scientific connotation and the spiritual essence understanding is not clear, on the construction of socialism with Chinese characteristics in some difficulties and problems can not correctly scientific comprehensive look at that of Marxism doubt, of the party and the country lose confidence.

The socialist core value system is not outstanding enough to guide the university campus cultural activity

The construction of campus culture is to give full play to the educational function, arming the people with scientific theories, with correct public opinion guide, imbue them with a noble spirit, and inspire them with excellent works to promote college students' all-round growth and success. At present, the campus cultural activities in Colleges and universities are becoming more and more colorful, but the overall campus culture is still significantly inadequate. Mainly reflected in: first, popular culture, the dominant cultural lack of attraction. Most student organizations activities grade is not high, most of the students after school life monotonous, limited to singing, playing games, playing chess and playing cards, QQ chat and so on, is full of desk culture, dormitory culture mostly lower style of popular culture. And for many of the party's basic knowledge, ideals and beliefs, cultural tradition, patriotism, etiquette and moral education students disagree, the lack of participation enthusiasm, cope with the presence of negative psychological and collective concept and responsibility consciousness indifferent, too much attention their own interests, lack of thinking for the future and fate of our nation. Second, recreational activities, less enlightening activities, activities of science and technology haven't really become the mainstream of campus culture, in the second classroom activities, the vast majority of knowledge type, paper type, recreational activities, academic, science and technology activities less, campus academic atmosphere is not strong, students learn underpowered, science and education combined with lack of achievements in scientific research.

The socialist core value system and the campus spirit of the degree of integration is not high enough

As the inner strength of the college students' survival and development, the campus spirit is the function of the school teachers and students, and it is the soul of campus culture.. Motto, emblem, and anthem, campus construction and campus environment the campus spirit is the most direct materialized form, easily bring teachers and students spiritual shock, emotional resonance to run a silent education guiding effect. Motto as Tsinghua University "self-improvement, Houdezaiwu", Beijing University of "patriotism, progress, democracy and science", Fudan University's erudite and Atsushi, cut asked and thought, Nankai University "to allow fair, with each passing day, China University of science and technology" Hong Zhuan and theory and practice blend "embody the characteristics of their own school, reflecting the combination of school education and national interests. But there are a considerable part of colleges and universities lack of school characteristics, School of thought and the tradition of 
sponsoring the concise, campus spirit lack of uniqueness and charisma, lack of historical heritage that staff and students to the school difficult to produce strong identity sense of feeling, a sense of belonging, sense of responsibility and honor. While in recent years, the development of higher education focus on improvement in the amount of expansion and the condition of running a school, but in the process of rapid development of many colleges and universities campus buildings lost the memory of history, campus environment, lack of cultural accumulation, dilute the school characteristics, especially some of the new University Park and the new campus building a one size fits all approach, style less distinctive, not only difficult to give a beauty to enjoy, and let a person very difficult to feel a school unique cultural influence. Undoubtedly, this campus culture construction of colleges and universities increased the difficulty.

\section{The concept and structure of college campus culture construction in the new situation}

Campus culture is the social culture based on university campus space, student, teacher-centered, teacher-student campus environment and practices for the carrier and spiritual culture as the core, the image of cultural, institutional culture and behavior culture a group unified organizational culture, including both material culture and immaterial culture.

Campus material culture, is the outer manifestation of the campus culture, including teaching and research facilities, work-life workplace and campus greening and beautifying the environment, embodies the ideals and humanistic spirit University. Culture is a system of norms and cultural practices, including teaching and research rules and regulations, organization and management of standardized regulations, and requirements of the student code of conduct, in addition to customary, ceremonial, school spirit, study and classes such as wind. Behavior culture is dynamic level campus culture, including teaching and research activities, organization and management, extracurricular cultural activities and even logistics services. Spiritual culture including historical and cultural traditions of the school, the school motto, school characteristics, psychological atmosphere and campus groups worldview, values, ethics and other factors.

Material culture, partitioning system culture, behavior and spiritual culture essentially covers the content of the campus culture. Mutual exchanges between these four interwoven to form a special influence on campus culture. Specifically, the material culture of campus culture is the most outward manifestation and symbol, it illuminates the historical accumulation level and style of the entire campus culture is the basis of other cultural forms of existence and development. Campus system culture is human activity guidelines, which regulate people as a means mandatory, it is by means of rewards and punishment on people's ideological orientation, have an important educational role function, to fully implement the guiding ideology and culture objectives of the final It has an important role to achieve. Behavior culture is the most active campus culture dynamic level, teachers and students based on the actions taken by certain educational purposes, and is reflected in the external value of teachers and students, campus culture mainly in campus behavior culture. Is the heart and soul of the spiritual and cultural campus culture, which reflects the special nature of a school, personality and spirit, embodies the mission of the school, the training objectives and its unique style, is the deepest cultural thing.

\section{Socialist core values to lead the construction of campus culture main content}

Socialist core values as a guide, strengthen the ideal and faith education. Hebei Agricultural University, university resources to rely century tradition Taihang Mountain, to establish their own brand. Positioned around the school, education goal and idea of educating people, to "promote the spirit of the Taihang Mountains, to become outstanding pillar of the state" for the guidelines, adhere to the "off fine,""off the small", "implement" focus, the details start thinning measures to promote and delicate, the socialist core values into effective teaching campus culture, social practice, cultural education and institution building.Adhere to start small, everyone can focus on to "relay Fruit 9301" volunteer service corps, "Ambassador mode queue ride" to "Agricultural good story," socialist core values education small plot Cheng Kung University, to guide students to consciously practice the socialist core values, the theoretical study into the students loved cultural activities on campus. He insisted from the real focus point, pay attention to the actual results, the establishment of joint mechanisms to ensure the dissemination of the three-dimensional effect; establishing a dynamic management mechanism to track progress in real time, so that the core values of socialism in the campus "ground gas", "into life", "the people".

To nurture university spirit, focusing on strengthening the construction of school spirit teaching style. Ethos, teaching style and the style of study is the soul of a university, the University is a valuable asset. Ethos, teaching style and the style construction of knowledge relating to the cultural quality of university students ideological and moral qualities, affect the quality of personnel training school.The Ministry of Education, Youth League Central "on strengthening and improving the construction of Campus Culture Opinions" that the Campus Culture to "to build good school spirit, teaching style, study style core", which gives the Campus Culture made clear requirements and direction.For this reason, one should correctly understand the function of the campus culture, to avoid the construction of campus culture tangible atheism. Second, we must follow the rules of the university campus culture 
construction, pay attention to the Hidden moral function of campus culture. In this process, to penetrate to the hidden culture by the dominant culture, to gradually form a second class-led socialist core value education.

Features educational activities as the starting point to achieve the unity of knowing and doing. Campus Culture to cultivate builders of socialism with Chinese characteristics as the goal of socialist core values of effective integration into education, the need to promote students' social practice in the process of "knowledge" and "line" unity.For this reason, it is necessary to carry out the socialist core values education programs construction, project mode of operation to take a series of cultural activities on campus, university students practice the socialist core values to create space. Hebei Agricultural University, to give full play to "focus time""the color of life Forum""pilot project" and other brands column advantages, set up transfer positive energy first.Continue to "focus time" playing the spread of ideological and political education of our school culture brand, "interactive" as a focal point to build up a platform for the exchange of ideas of equality, guided without preaching, indoctrination, so that the hearts of the students in-depth education, produce resonate. In "the color of life Forum" as the carrier, further strong cultural atmosphere on campus, to enhance our students ideological and moral standards and quality humanities and social sciences.Push forward the "pilot project" to strengthen the nascent class work, and strive to create a "mentoring" atmosphere so that new students feel that is a hundred years universities Zonta, pragmatic, seeking spirit, the campus culture began to take root in students' thinking, stimulate nascent work hard.

Modern information technology as the basis to create a new network of cultural highlights.On the one hand the continuous development and improvement of micro disseminate educational platform. Actively adapt to the era of micro-convenience, diversity, permeability and other characteristics, and actively build schools, colleges, grade, class, community five levels microarchitecture; and actively adapt to the micro-channel in college students increasingly widespread application characteristics, and strive to create distinctive students love the public micro-channel platform.On the other hand the spread expanding educational way. For mobile client users of fragments of time gold, media usage scenarios, information push and other characteristics fixed, mobile and actively expand the socialist core values of the dissemination of educational pathways; adapt media forms of communication from "one to many" to "many to many" change, and "everyone is a reporter, everyone has the microphone," the new media age, and actively expand the spread of socialist core values interactive educational approach;Give full play to lead the literary value, the soul shape, such as the role and function of mold sentiment, by conducting campus cultural activities and other forms, and actively promote the socialist core values of cultural transmission educational way.

\section{Conclusion}

Results socialist core values to lead the construction of campus culture, one in Campus Culture during the Socialist core values, thereby promoting the socialist core values in universities can be widely spread and promote, thereby bringing all members of society to society doctrine recognized core values, identity, acceptance and practice, so that the core values of socialism in the whole society to confirm it and develop.Second, the socialist core values and promote the construction of campus culture, to enrich and develop the form and content of campus cultural construction, endowed with Campus Cultural Construction of the new vitality. Both are closely linked, mutual coordination and promote common development.

\section{References}

[1]. X.M.Sun,W.M.Dai,"AnAnalysis of the Countermeasures towards the Integration of Core SocialistValues into Ideological and Political Education for College Students", Journal of Southern Vocational Educaton, pp. 44-48,2015.

[2]. K.P.Tang, J.J. Lu, "Research on the Path of Core Socialist Values Leading the Construction of Campus Culture", Journal of Xingtai Polytechnic College, pp.35-37,2015.

[3]. B.J.Dong,Z.H.Zhang,H.Y.Zou, "Core Socialist Values and Construction of Campus Culture in Colleges and Universities",Journal of College Counselors,pp.1-3,2014.

[4]. T.Y.Yin, "On the Path of Integrating Core Socialist Values into Ideological and Political Theory Course Teaching",Journal of HuBei Adult Education Institute, pp.34-35,2014.

[5]. J.H.Wen, "On the Route of Constructing Collage Campus Culture Based on Cultivating and Practicing Core Socialist Values",Journal of Zhejiang Business Technology Institute, pp.47-50,2014.

[6]. Y.Xiong,"The socialist core value system and the campus culture construction of University",Ideological and Political Education Research, pp.118-121,2011.

[7]. Ancis J R, Sedlacek W E, Mohr J J. "Student perceptions of campus cultural climate by race", Journal of Counseling \& Development, pp.180-185, 2000.

[8]. Parker Hannifi. The cultural nature of human development. Oxford University Press, USA,2003.

[9]. http://cpc.people.com.cn/GB/64093/64094/16778578. html. 